\title{
Ulotne duchy
}

\section{Indianie w poezji Philipa Freneau i Williama Cullena Bryanta a koncepcje rasowe dziewiętnastowiecznej nauki}

W poezji amerykańskiej Indianie zyskali szczególną popularność na początku XIX wieku. Widać to dobrze w twórczości dwóch czołowych poetów wczesnego amerykańskiego romantyzmu - Philipa Freneau i Williama Cullena Bryanta. Freneau (1752-1832), nazywany poetą rewolucji amerykańskiej, pisał głównie utwory patriotyczne; rdzenni mieszkańcy Ameryki pojawiali się w jego twórczości najczęściej jako element przeszłości, na którą patrzy się ze smutkiem i nostalgią. Bryant (1794-1878) był jednym z najpopularniejszych amerykańskich poetów XIX wieku - jego najbardziej znane wiersze to Thanatopsis, który napisał w wieku siedemnastu lat, oraz równie wczesny Do ptaka wodnego. Motyw Indian w poezji Bryanta jest, jak ukaże niniejszy artykut, nieco bardziej skomplikowany niż u Freneau; widać jednak wyraźnie paralele między ujęciem tego tematu w twórczości obu poetów a koncepcjami naukowymi na temat rasy, obecnymi w XIX wieku.

Popularność Indian wśród amerykańskich romantyków wynikała z tego, że tacy pisarze jak Freneau czy Bryant, podobnie jak europejscy poeci tego okresu, zwracali się ku naturze, krytykując cywilizację jako zepsutą, a podziwiając szczerość i prostotę Indian, postrzeganych jako „szlachetne dzikusy”. Dla Ameryki figura „szlachetnego dzikusa” miała w tym okresie dodatkowe znaczenie: uosabiała również Stany Zjednoczone. Ameryka na początku XIX wieku, jako młode państwo, nie zdążyła wytworzyć jeszcze wielu dzieł kultury, amerykańscy artyści czuli się zaś „ubogimi krewnymi” Europy. Bez tradycji, bez historii, mogli tylko naśladować europejskie wzorce. Romantyczny zwrot ku naturze pozwolit im uznać, że również ich kontynent ma coś do zaoferowania, a brak tradycji daje im świeżość spojrzenia. „Zbyt długo słuchaliśmy dworskich muz Europy” - pisał poeta Ralph Waldo Emerson w eseju The American Scholar, obwieszczając, że odtąd Amerykanie powinni zacząć przemawiać własnym głosem. Nic więc dziwnego, że Indianie, postrzegani 
jako dzieci natury, dalekie od społecznego naśladownictwa, budzili sympatię pisarzy tego okresu.

Zainteresowanie Indianami oznaczało często, że poeci opowiadali się po ich stronie w konflikcie z cywilizacją białych - działała tu zasada przedkładania natury nad kulturę. W wierszu Indianin w miejscu pochówku swoich ojców (An Indian at the Burial-Place of his Fathers) Bryant opisuje Indianina patrzącego na tereny, które kiedyś zajmowało jego plemię, a które obecnie są własnością białych. Mimo niewątpliwej malowniczości owiec i krów pasących się na łące bohater (a również i sam autor, jak można wnioskować z tonu wiersza) tęskni za czasami, gdy te obszary porastały lasy. Chodzi nie tylko o to, że dziki krajobraz wydawał mu się piękniejszy, ale również o fakt, że miasteczka białych wybudowane są na sprofanowanych grobach indiańskich, a osadnicy „Będą prowadzić pług wśród ich kości” (Bryant, 1840: 215, tłum. J.F.). Należy przy tym zauważyć, że dla samego Bryanta kwestie estetyczna i religijna wydają się tak samo istotne; przekonania religijne Indian są tu rekwizytem poetyckim traktowanym na równi z potrzebą piękna krajobrazu.

Podobnie Freneau w znanym wierszu Cmentarzysko indiańskie (The Indian Burying Ground) wyraźnie opowiada się po stronie kultury rdzennych mieszkańców Ameryki. W duchu tzw. poetów cmentarnych (graveyard poets) przedstawia swoje rozważania nad śmiercią, sprowokowane wizytą na indiańskim cmentarzysku. W przeciwieństwie do białych Indianie grzebią swoich zmarłych nie w pozycji leżącej, a siedzącej, co według poety oznacza nadzieję nie na wieczny sen, ale na przyszłe życie, będące kontynuacją życia doczesnego. Ten rodzaj pochówku wydaje mu się bliższy, bo tchnie nadzieją odnoszącą się do zaświatów. Przy tym poeta zrównuje kulturę białych z oświeceniowym racjonalizmem, natomiast zwyczaje Indian z czymś tajemniczym i, nomen omen, romantycznym. Otwiera wiersz sprzeciwem wobec uczonych, którzy twierdzą, że pozycja umarłych nie ma znaczenia; słowa „Uczeni, dysputujcie sobie” (Barańczak, 1998: 24) to ten sam rodzaj niezgody na czysty intelektualizm, co Mickiewiczowska krytyka „mędrca szkiełka i oka”. W ostatniej zaś strofie Freneau stwierdza: „A rozum przed tym, co go łudzi, / Padnie trwożliwie na kolana!” (Barańczak, 1998: 24). W oryginale rozum „pada na kolana” przed „cieniami i marami” - jeszcze wyraźniej widać zatem, że to, co zupełnie niejasne i niewytłumaczalne (uosabiane przez Indian) ma zatriumfować nad intelektualną oczywistością.

Fakt, że bohater wiersza Freneau znajduje się na cmentarzu, nie jest przypadkowy. Przygląda się temu, co pozostało z niegdyś wspaniałej kultury. W 1787 roku, kiedy powstał ów tekst, na Wschodnim Wybrzeżu Indianie nie stanowili już militarnego zagrożenia. Sentymentalne, nostalgiczne portrety ich cywilizacji zaczęty pojawiać się w literaturze amerykańskiej w momencie, kiedy pisarze mieszkający na wschodzie Ameryki, bo tam skupiało się życie intelektualne kraju, nie mieli 
już styczności z „prawdziwymi”, „dzikimi” Indianami. I nawet jeśli wiele narodów indiańskich nadal istniało, w kulturze traktowano Indian jako „zawsze już martwych” (always already dead) (Brantlinger, 2003: 59, tłum. J.F.). Patrick Brantlinger twierdzi, że podstawowym gatunkiem literackim tego okresu w Ameryce jest elegia proleptyczna - opłakiwanie ludzi, którzy co prawda jeszcze żyją, ale ich nadchodząca zagłada jest tak pewna, że traktuje się ich w zasadzie jak już należących do przeszłości (Brantlinger, 2003: 3-4). Podkreśla również, że podobnie do eposu, elegia proleptyczna jest gatunkiem scalającym wspólnotę narodową; sentymentalne przedstawienie wymierających Indian pozwalało białym Amerykanom pogodzić się z faktem, że sami zajmują ich miejsce. Według Brantlingera mistrzem elegii proleptycznej jest James Fenimore Cooper, który sprawnie łączył opłakiwanie odejścia Indian z przekonaniem, że zgodnie z nieubłaganym prawem postępu biali muszą zająć ich miejsce (Brantlinger, 2003: 62).

Dyskurs "ginących rdzennych Amerykanów” (the dying American) nie ograniczał się zresztą w tym okresie jedynie do literatury. W XIX wieku powszechne było przekonanie, że Indianie skazani są na zagładę - stąd na przykład malarz George Catlin stworzył galerię portretów indiańskich, aby uwiecznić cywilizację, która, jak sądzit, odchodziła w przeszłość. W latach czterdziestych Catlin podróżował po Europie w towarzystwie pracujących dla niego Indian, pokazując swoją kolekcję obrazów, a także indiańskiego rękodzieła i przedmiotów rytualnych, co spotkato się z dużym zainteresowaniem w Wielkiej Brytanii i Francji. Również dziewiętnastowieczna nauka potwierdzała, że Indianie skazani są na zagładę; uważano, że są oni fizycznie słabsi, ponieważ nie należą do żadnej z trzech podstawowych ras (czarnej, mongoloidalnej ani białej) (Brantlinger, 2003: 39). Sądzono również, że „dzikość” Indian stanowi o ich słabości w obliczu kontaktu z cywilizacją, dlatego charakteryzują się oni podatnością na zagrożenia niesione przez europejską kulturę, takie jak uzależnienie od alkoholu, nie potrafią natomiast korzystać z jej dobrodziejstw (Dippie, 1982: 35). Dzięki przekonaniu, że zniknięcie Indian jest nieuniknione i uwarunkowane biologicznie, biała Ameryka pozbywała się poczucia winy za ich skandaliczne traktowanie i usprawiedliwiała wysiedlenia Indian na zachód jako humanitarną próbę ocalenia ich przed pokusami cywilizacji.

Nic więc dziwnego, że Indianie jako ginąca rasa to jeden z ulubionych tematów amerykańskiej poezji romantycznej. Freneau w wierszu Proroctwo króla Tammany'ego (The Prophecy of king Tammany) odwołuje się do historycznej postaci jednego z wodzów Lenni-Lenape, żyjącego w XVII wieku (Freneau, 1809: 269-271). Na widok białych nadciągających z Europy do Nowego Świata Tammany przepowiada, że ich nadejście oznacza koniec cywilizacji indiańskiej. Zwycięstwo białych jest nieuniknione, Indianie nie są w stanie się im przeciwstawić. Dlatego Tammany 
postanawia umrzeć na sam widok białych osadników: buduje stos pogrzebowy i osiąga wyzwolenie od ziemskich kłopotów. W ten sposób postać Tammany'ego staje się synekdochą całego jego narodu: oto niebawem ze wszystkimi Indianami stanie się to samo co $z$ ich wodzem. Biali w zasadzie nie mają $w$ tym procesie żadnego udziału; Tammany nie czeka, aż zadadzą mu śmierć, tylko wyręcza ich, wiedząc, że to, co nieuniknione i tak musi nadejść. Podobnie jest z innymi „ginącymi rdzennymi Amerykanami” - „topnieją” oni przed nadchodzącymi białymi jak śnieg; nie są mordowani, a po prostu znikają. Dla Freneau Indianie to „ulotne duchy", jak nazywa on innego umierającego Indianina z wiersza Umierający Indianin Tomo-Chequi (The Dying Indian Tomo-Chequi) (Bryant, 1860: 16).

Zgodnie z duchem elegii proleptycznej poeci romantyczni wyrażali żal, że Indianie zniknęli ze wschodniej części Ameryki. Bohater wiersza Bryanta Spacer o zachodzie słońca (A Walk at Sunset) przechadza się po lesie niegdyś zamieszkałym przez „Pokolenia wojowników [które] nadeszły i przeminęły” (Bryant, 1840: 242, tłum. J.F.). To samo słońce, które kiedyś zachodziło nad polującymi plemionami indiańskimi, zachodzi teraz nad białymi - będąc niezmiennym elementem natury, świadkiem nieuniknionych zmian toczących się w ludzkim świecie. Jak zauważa Agnieszka Salska, „życie ciągle przemijające w swoich indywidualnych formach, ale wieczne w swojej istocie" to jeden z ulubionych motywów poezji Bryanta (Salska, 1988: 92, tłum. J.F.). Co ciekawe jednak, w nostalgicznej wizji przedstawionej w Spacerze o zachodzie słońca nie ma miejsca na rozważania na temat tego, dlaczego Indianie zniknęli. Wydaje się, że Bryant mówi o jakimś naturalnym procesie, a nie o efekcie podboju.

Podobnie wygląda to w najbardziej znanym i najciekawszym wierszu Bryanta o tematyce indiańskiej pt. Prerie. Bohater utworu - podróżnik ze Wschodniego Wybrzeża - znajduje się na środku prerii, której ogrom przywodzi mu na myśl ocean (o popularności takiego porównania w poezji romantycznej mogą świadczyć na przykład Stepy akermańskie Adama Mickiewicza). Patrząc na grobowce $w$ formie kurhanów, które spotyka na amerykańskim Środkowym Zachodzie, wyobraża sobie ich budowniczych - tajemniczą rasę miłującą pokój, prowadzącą idylliczne, rolnicze życie. Arkadyjskość tej wizji zostaje zburzona przez nadejście czerwonoskórych wojowników; pojmane w trakcie walk kobiety zostają żonami zdobywców, a wcześniejsza kultura znika. Bohater zauważa stoicko: „Tak zmienia się forma bytu" (Bryant, 1840: 53, tłum. J.F.). W ostatniej strofie przedstawia wizję prerii opuszczonej również przez czerwonoskórych wojowników, na którą nadciągają tym razem biali osadnicy.

Odczytanie tego wiersza w kontekście innych utworów Bryanta jako po prostu dotyczącego „kosmicznego prawa stałości i zmiany” (Salska, 1988: 95, tłum. J.F.) 
jest problematyczne, ponieważ tekst ten pod powierzchnią uniwersalnych rozważań o przemijaniu jest głęboko polityczny. Został on napisany w 1832 roku, dwa lata po podpisaniu przez prezydenta Andrew Jacksona tzw. Ustawy o usunięciu Indian (Indian Removal Act), wysiedlającej plemiona zamieszkujące południową część Stanów Zjednoczonych na zachód od Missisipi i skutkującej śmiercią znacznej części populacji migrującej na „Szlaku Łez”. Bryant popierał politykę Jacksona - sądzit, że „dzicy” nie mogą pokojowo współegzystować z „cywilizowanymi” białymi oraz że wysiedlenie za Missisipi odbędzie się z korzyścią dla samych Indian, nieprzystosowanych do bliskich kontaktów z cywilizacją (Galloway, 2010: 727). W kontekście przekonań politycznych Bryanta widać, że wiersz Prerie w oczywisty sposób usprawiedliwia ekspansję białych na zachód. Skoro Indianie wymordowali wcześniejszą, pokojowo nastawioną cywilizację, biali Amerykanie nie muszą mieć poczucia winy, jeśli robią to samo wobec Indian. Odwieczne prawo natury głosi, że świat podlega zmianom, a jeden lud zastępuje kolejny - taki jest sens fragmentu o „zmieniającej się formie bytu”. W ten sposób historia przestaje być w wizji Bryanta przedmiotem konkretnych decyzji podejmowanych przez ludzi, a zostaje wpisana w rytm kosmicznego porządku, na który człowiek nie ma wpływu. Co więcej, w Preriach Bryant nie odnosi się nawet do wojen amerykańsko-indiańskich. Pisze, że Indianin „opuścił” prerie i „odszedł szukać / Dzikszej krainy łowów” (Bryant, 1840: 53, tłum. J.F.), tak jakby zrobił to z własnej woli'. Osadnicy, których wyobraża sobie bohater wiersza, nadciągają na tereny już opustoszałe. Wymienione zostają jedynie nadchodzące kobiety, dzieci i ludzie pobożni - jest to więc fantazja o pokojowym, bezkrwawym podboju, zupełnie sprzeczna z prawdą historyczną.

Agnieszka Salska zwraca uwagę na „zdystansowaną pozycję” bohatera mówiącego w Preriach, który opisuje samą prerię, później przechodzi do wizji dziejów jej mieszkańców, po czym klamrowo powraca do swojej pozycji samotnego jeźdźca, niezmienionego przez doświadczenie wykreowane w wierszu (Salska, 1988: 97). W takiej „zdystansowanej pozycji” można upatrywać jeszcze jedną strategię przedstawienia białych jako niewinnych - tym razem dotyczyłaby ona białego bohatera wiersza. Mary Louise Pratt pisze o figurze obserwatora w tekstach podróżniczych jako o ideologicznym konstrukcie: postrzeganie przedstawia się w tym gatunku literackim jako bierne, a w związku z tym niegroźne, pozornie nieszkodliwe w porównaniu do imperialistycznego podboju (Pratt, 1995: 67). Podobnie wygląda to u Bryanta - jego bohater to tylko bierny obserwator, kronikarz, przed którego oczyma wyobraźni rozgrywa się dramat historii - bez jego udziału.

1 Podobny obraz pojawia się w wierszu Bryanta Indianin w miejscu pochówku swoich ojców, gdzie tytułowy Indianin stwierdza:„A oni nadciągają, kiedy my / Zdążamy ku zachodzącemu słońcu". Zachowany jest więc podobny, historycznie nieprawdziwy porządek: biali nadchodzą na tereny opuszczane przez Indian, nie ma tu miejsca na żaden zbrojny konflikt (Bryant, 1840: 215). 
Andrew Galloway twierdzi, że Bryant bronił prawa białych Amerykanów do wysiedlania Indian nie ze względu na niechęć do samych Indian, ale z powodu „lęku o kruchość własnej tożsamości kulturowej” (Galloway, 2010: 741). Przekonanie, że biała Ameryka istnieje w jakimś rodzaju zagrożenia, widać w niektórych tekstach wspomnianych poetów, gdzie ów „naturalny” bieg zmian sięga również w przyszłość. W wierszu Bryanta Indianin w miejscu pochówku swoich ojców tytutowy Indianin stwierdza, że również biali mogą pewnego dnia zniknąć tak jak jego rasa. W Proroctwie króla Tammany'ego Freneau Tammany podobnie przepowiada, że również biali kolonizatorzy zostaną zaatakowani - jednak w tym przypadku jest to proroctwo dotyczące amerykańskiej wojny o niepodległość, a zewnętrzni agresorzy to Brytyjczycy, przedstawieni przez patriotę Freneau jako „obcy”. Żaden z tych dwóch przykładów nie czyni koncepcji naturalnego następstwa ludów mniej problematyczną. Bryant nadal sugeruje, że ludobójstwo Indian przez Amerykanów nie jest niczym wyjątkowym, skoro i ci drudzy mogą w jakiejś fantastycznej przyszłości paść ofiarą kolejnej cywilizacji. Freneau dodatkowo wprowadza porównanie między zajmowaniem ziemi Indian przez białych osadników a rewolucją amerykańską, która, jakkolwiek krwawa, była jednak konfliktem między stronami mającymi znacznie bardziej wyrównane szanse i w której stawką nie było zniknięcie całej cywilizacji.

Obecny w Preriach wątek istnienia tajemniczej rasy poprzedzającej Indian nie pochodzi od Bryanta. W dziewiętnastowiecznej Ameryce trwała zagorzała dyskusja na temat „budowniczych kurhanów” (mound builders). Większość naukowców uważała, że grobowce nie mogły zostać wzniesione przez współcześnie znanych Indian, ale zostały zbudowane przez wymarłą już rasę; istnieli nawet tacy, którzy sugerowali, że była to rasa biała (Pace, 2009: 198). Kraniolog Samuel George Morton, porównujący czaszki przedstawicieli różnych ras w latach czterdziestych XIX wieku twierdził co prawda, że według rezultatów jego badań budowniczowie kurhanów należeli do tej samej rasy co współcześni mu Indianie, jednak należał on do mniejszości. Sądzono przede wszystkim, że „dzicy” Indianie nie byli w stanie wznieść na tyle wymagających struktur. Natomiast koncepcja mitycznych „budowniczych kurhanów" pociągała za sobą wiele korzyści: przede wszystkim dzięki niej Ameryka zyskiwała historię, której brak tak często zarzucali jej Europejczycy. Ponadto ich domniemane istnienie pozwalało odeprzeć popularną w tym okresie teorię Georges'a-Louisa Leclerca hrabiego de Buffon, przedstawioną w jego Historii naturalnej, głoszącą, że klimat Ameryki powoduje degenerację żyjących w nim organizmów. Dowodem na to miałaby być według Buffona fizyczna niedoskonatość północnoamerykańskich Indian, a także fakt, że nie stworzyli oni wielkiej cywilizacji. Była to kwestia o tyle istotna, że zgodnie z teorią Buffona amerykański klimat powinien doprowadzić również do degeneracji żyjących w nim białych - zrozumiałe 
jest więc, że amerykańskim pisarzom i uczonym zależało na dowiedzeniu, że Buffon się mylit. Argumenty o niedostatkach fizycznych odpierat na przykład Thomas Jefferson w Notatkach o Stanie Wirginia; jeśli zaś chodzi o brak cywilizacji, „budowniczowie kurhanów" pozwalali zadać kłam temu twierdzeniu (Miller, 1949: 229). Również przekonanie, że owa tajemnicza rasa została wymordowana przez Indian, było w XIX wieku powszechne; uważano, że hordy najeźdźców z Azji, po przedostaniu się przez Cieśninę Beringa, zaatakowały „budowniczych kurhanów”, albo że to wręcz liga Irokezów odpowiadała za eksterminację wcześniejszych mieszkańców prerii (Dahl, 1961: 183). Podobnie wypieranie jednych gatunków przez inne, w tym jednych ludów przez drugie, nauka (głównie w osobie angielskiego geologa Charlesa Lyella) uznawała za naturalne i oczywiste (Brantlinger, 2003: 28). „Kosmiczna” wizja Bryanta jest więc odzwierciedleniem poglądów szeroko rozpowszechnionych w jego czasach.

Sposób, w jaki poeci XIX wieku przedstawiali Indian w swoich utworach, stanowił część szerszego dyskursu na temat rasy w tym okresie. Jak widać na przykładzie poezji Freneau i Bryanta, traktując Indian jako „ginących rdzennych Amerykanów”, skazanych na zagładę przez swoją biologiczną „słabość” i brak odporności na pokusy cywilizacji, oraz odwołując się do tajemniczej rasy „budowniczych kurhanów" podbitej przez czerwonoskórych wojowników, poeci czerpali ze wspótczesnych im koncepcji naukowych i utrwalali je w powszechnej świadomości.

\section{Bibliografia}

BarańczakS. (przeł. i oprac.) (1998), Od Walta Whitmana do Boba Dylana. Antologia poezji amerykańskiej, Kraków:Wydawnictwo Literackie. Brantlinger P. (2003), Dark Vanishings: Discourse on the Extinction of Primitive Races, 1800-1930, Ithaca-London: Cornell University Press. Bryant W.C. (1840), Poems, New York: Harper and Brothers.

Bryant W.C. (red.) (1860), Selections from the American poets, New York: Harper and Brothers.

Dahl C. (1961), Mound-Builders, Mormons, and William Cullen Bryant, ,Ihe New England Quarterly", vol. 34(2), s. 178-190, http://dx.doi. org/10.2307/362525

Dippie B.W. (1982), The Vanishing American: White Attitudes and U.S. Indian Policy, Lawrence: University Press of Kansas.

Freneau P. (1809), Poems, t. 1, Philadelphia: Lydia R. Bailey.

Galloway A. (2010), William Cullen Bryant's American Antiquities: Medievalism, Miscegenation, and Race in The Prairies, „,American Literary History", vol. 22(4), s. 724-751.

Miller R.N. (1949), Nationalism in Bryant's 'The Prairies', „„American Literature”, vol. 21(2), s. 227-232.

Pace J. (2009), William Wordsworth, William Cullen Bryant and the poetics of American Indian Removal, [w:] T. Fulford, K. Hutchings (red.), Native Americans and Anglo-American Culture, 1750-1850: The Indian Atlantic, New York: Cambridge University Press, s. 197-216.

Pratt M.L. (1995), Imperial Eyes: Travel Writing and Transculturation, London-New York: Routledge.

Salska A. (1988), William Cullen Bryant's 'The Prairies': toward Whitmanian sense of form in the poem, „Acta Universitatis Lodziensis. Folia Litteraria", nr 24, s. 91-102. 